\title{
A new species of Fissimentum Cranston \& Nolte, 1996 from the state of São Paulo, Brazil (Diptera: Chironomidae, Chironominae)
}

\author{
Trond Andersen ${ }^{1}$ \\ Luiz Carlos Pinho ${ }^{2 *}$ \\ ${ }^{1}$ Department of Natural History, University Museum of Bergen, University of Bergen \\ P.O. Box 7800, NO-5020 Bergen, Norway \\ ${ }^{2}$ Universidade Federal de Santa Catarina, Centro de Ciências Biológicas \\ Departamento de Ecologia e Zoologia, CEP 88.040-901, Florianópolis - SC, Brazil \\ * Corresponding author \\ luiz.pinho@ufsc.br
}

Submetido em 25/06/2019

Aceito para publicação em 30/09/2019

\section{Resumo}

Uma nova espécie de Fissimentum Cranston \& Nolte, 1996 do estado de São Paulo, Brasil (Diptera: Chironomidae, Chironominae). Fissimentum mendesi $\mathrm{n}$. sp. é descrita e ilustrada com base em machos coletados com armadilhas luminosas em duas localidades no estado de São Paulo, Brasil. A nova espécie é aparentemente relacionada a $F$. desiccatum Cranston \& Nolte, 1996 e F. guairense Pinho \& Froehlich, 2011 por apresentar uma projeção posterior no tergito IX, mas pode ser facilmente separada de seus congêneres pela combinação de uma volsela superior curta, robusta, uniformemente curva, e AR em torno de 1,5. Uma chave revisada para os machos do gênero é fornecida.

Palavras-chave: Chave; Descrição; Região Neotropical; Taxonomia

\section{Abstract}

Fissimentum mendesi $\mathrm{n}$. sp. is described and figured on the basis of males collected in light traps in two localities in the state of São Paulo, Brazil. The new species is apparently closely related to $F$. desiccatum Cranston \& Nolte, 1996 and F. guairense Pinho \& Froehlich, 2011 by having a posterior projection of tergite IX, but can easily be distinguished from its congeners on the combination of a short, stout, evenly curved superior volsella and an antennal ratio of about 1.5. A revised key to the males of the genus is provided.

Key words: Description; Key; Neotropical region; Taxonomy

\section{Introduction}

The genus Fissimentum was erected by Cranston and Nolte (1996) on the basis of the larvae, pupae and adults of F. desiccatum Cranston \& Nolte, 1996 from the state of Mato Grosso, Brazil. Larvae of Fissimentum were described by Roback (1966) as "Tendipedini genus A", but the larvae were not reared and thus not associated with the pupa and adults. Larvae of this taxon have been recorded in the southern USA, throughout Central 
and South America, ranging from the Peruvian Andes to tropical and subtropical lowland areas in Brazil, and Australia as well (CRANSTON; NOLTE, 1996; ROBACK, 1966; EPLER, 2009).

More recently, Pinho and Froehlich (2011) described three additional Fissimentum species from Brazil and provided a key to the species. Below, we describe a fifth species from Brazil and revise the previous key (PINHO; FROEHLICH, 2011). The new species is apparently closely related to $F$. desiccatum and F. guairense Pinho \& Froehlich, 2011 by having a posterior projection of tergite IX. It was collected in light traps at two localities in Furnas do Bom Jesus State Park in the state of São Paulo.

\section{Material and Methods}

The specimens examined were mounted on slides in Canada balsam or Euparal following the procedure outlined by SÆTHER (1969). Morphological terminology follows Sæther (1980), and measurements are given as ranges. Coloration is based on slide-mounted specimens.

The holotype will be housed in the Museu de Zoologia da Universidade de São Paulo, São Paulo, Brazil (MZUSP), and one paratype will be kept in the entomological collection at Departamento de Ecologia e Zoologia, Universidade Federal de Santa Catarina (UFSC) and one in the Department of Natural History, University Museum of Bergen, Bergen, Norway (ZMBN).

\section{Results}

\section{Fissimentum Cranston \& Nolte}

Fissimentum Cranston \& Nolte, 1996: 1.

Type species: Fissimentum desiccatum Cranston \& Nolte, 1996: 9.

Other included species: F. fordlandense Pinho \& Froehlich, 2011; F. guairense Pinho \& Froehlich, 2011; F. mateusi Pinho \& Froehlich, 2011; F. mendesi n. sp.
The genus was described in detail by Cranston and Nolte (1996) on the basis of males, females, pupae and larvae of $F$. desiccatum from Mato Grosso State, Brazil.

\section{Key to the males of Fissimentum Cranston \& Nolte}

1. Tergite IX with posterior projection. ... 2

- Tergite IX without posterior projection. ... 4

2. Squama with $17-25$ setae; $\mathrm{R}_{1}$ with $0-5$ setae, $\mathrm{R}_{4+5}$ with 1-2 apical setae. ... 3

- Squama with $12-13$ setae; $\mathrm{R}_{1}$ with $8-13$ setae, $\mathrm{R}_{4+5}$ with 12-13 apical setae (CRANSTON; NOLTE, 1996, Figures 3 and 6).... Fissimentum desiccatum Cranston \& Nolte

3. Gonocoxite with well-developed, flap-like, posteriorly bent ventromedial projection. AR 1.91-2.11 (PINHO; FROEHLICH, 2011, Figures 2 and 3). ... Fissimentum guairense Pinho \& Froehlich

- Gonocoxite without flap-like, posteriorly bent ventromedial projection. AR 1.52-1.57 (Figures 1-4).

... Fissimentum mendesi n. sp.

4. Gonocoxite with well-developed ventromedial projection. $\mathrm{R}_{4+5}$ with setae only at apex (PINHO; FROEHLICH, 2011, Figure 1). ... Fissimentum fordlandense Pinho \& Froehlich

- Gonocoxite without ventromedial projection. $\mathrm{R}_{4+5}$ with setae distributed all over the vein (PINHO; FROEHLICH, 2011, Figure 4). ... Fissimentum mateusi Pinho \& Froehlich

Fissimentum mendesi n. sp.

(Figures 1-4)

\section{Type material}

Holotype male, Brazil, São Paulo, Pedregulho, Furnas do Bom Jesus State Park, Córrego Bom Jesus, 20¹4'38'S 47²7'48'W, 930 m a.s.1., 14 September 2007, light trap, leg. L. C. Pinho et al. (MZSP). Paratypes: 1 male, same as holotype except (UFSC); 1 male, same as holotype except: Furna São Pedro, 2009'10’S 47³0’38’W, 573 $\mathrm{m}$ a.s.1., 16 October 2000, light trap, leg. T. Andersen \& H. F. Mendes (ZMBN). 


\section{Diagnostic characters}

Fissimentum mendesi n. sp. Can be easily distinguished from its congeners on the following combination: a short, stout, evenly curved superior volsella; tergite IX with posterior, subquadrangular extension; and AR of about 1.5.

\section{Description}

Male $(\mathrm{n}=3)$. Total length 4.52-5.12 mm. Wing length 1.98-2.12 mm. Total length/wing length 2.28-2.42. Wing length/length of profemur 2.31-2.34.

Coloration. Head, thorax and abdomen brown; legs brown with all tarsi light brown, wings light brown with slightly darker shades along veins.

Antenna. Antennal ratio (AR) 1.52-1.57. Ultimate flagellomere 709-780 $\mu \mathrm{m}$ long.

Head (Figure 1). Temporal setae 18-20; including 2 inner verticals, 10-13 outer verticals bi- to triserial, and 3-4 postorbitals. Clypeus with 18-21 setae. Tentorium 157$187 \mu \mathrm{m}$ long, $49-57 \mu \mathrm{m}$ wide. Stipes $157-182 \mu \mathrm{m}$ long, 13-21 $\mu \mathrm{m}$ wide. Palp segment lengths (in $\mu \mathrm{m}$ ): 37-49, 47-49, 157-180, 132-137, 195-198. Third palpomere with 2 sensilla apically, longest 15-21 $\mu \mathrm{m}$ long.

Thorax. Antepronotum without seta. Dorsocentrals 8-9; acrostichals 11-13, biserial, starting some distance from antepronotum; prealars 3; supraalar 1. Scutellum with 7-8 setae.

Wing (Figure 2). Venarum ratio (VR) 1.10-1.12. Brachiolum with 2 setae, $\mathrm{R}$ with 11-14, $\mathrm{R}_{1}$ with 2-5, $\mathrm{R}_{4+5}$ with $1-2$, and other veins and cells bare. Squama with 17-20 setae.
Legs. Scale of fore tibia 20-28 $\mu \mathrm{m}$ long, spur of mid tibia 35-39 $\mu \mathrm{m}$ long, spur of hind tibia 39-44 $\mu \mathrm{m}$ long. Combs on mid tibia 20-23 and 19-20 $\mu \mathrm{m}$ long, combs on hind tibia 25-28 and 21-25 $\mu \mathrm{m}$ long. Width at apex of fore tibia $52-57 \mu \mathrm{m}$, of mid tibia 55-59 $\mu \mathrm{m}$, of hind tibia $63-65 \mu \mathrm{m}$. Lengths and proportions of legs shown in Table 1.

FIGURE 1: Fissimentum mendesi n. sp., male. Head.

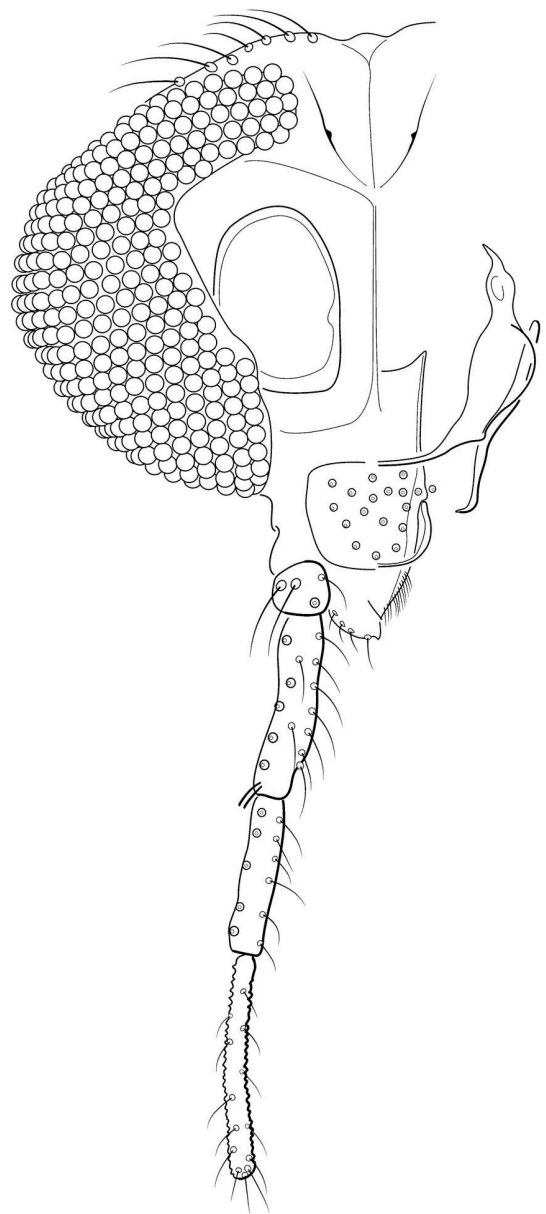

FIGURE 2: Fissimentum mendesi n. sp., male. Wing (Photograph, Hege Avsnes Dale).

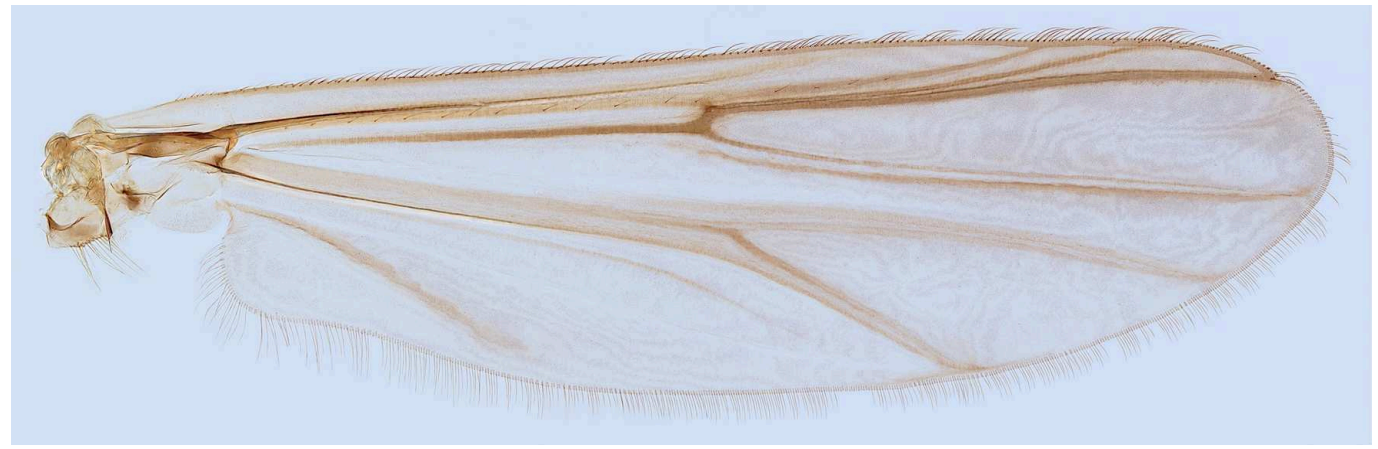


TABLE 1: Lengths (in $\mu \mathrm{m}$ ) and proportions of legs of Fissimentum mendesi sp. n., male $(\mathrm{n}=3)$. LR $=$ Leg ratio, $\mathrm{BV}=$ "Bein-Verhältnisse", SV = "Schenkel-Schiene-Verhältnis", BR = Bristle ratio.

\begin{tabular}{|c|c|c|c|c|c|c|}
\hline & fe & ti & $\mathrm{ta}_{1}$ & $\mathrm{ta}_{2}$ & $\mathrm{ta}_{3}$ & $\mathrm{ta}_{4}$ \\
\hline$p_{1}$ & $857-874$ & $512-531$ & $1182-1283$ & 808-899 & $512-564$ & $433-441$ \\
\hline $\mathbf{p}_{2}$ & $847-899$ & $758-857$ & $480-498$ & $207-221$ & $148-155$ & $95-98$ \\
\hline \multirow[t]{2}{*}{$\mathbf{p}_{3}$} & $837-858$ & $857-907$ & $729-735$ & $364-392$ & 284-294 & $167-172$ \\
\hline & $\mathrm{ta}_{5}$ & LR & & & & BR \\
\hline$p_{1}$ & $188-197$ & $2.31-2.42$ & & & & $1.67-2.33$ \\
\hline $\mathbf{p}_{2}$ & $75-80$ & $0.62-0.63$ & & & & $2.20-3.47$ \\
\hline $\mathbf{p}_{3}$ & $84-98$ & $0.81-0.85$ & & & & $3.40-4.24$ \\
\hline
\end{tabular}

Hypopygium (Figures 3-4). Tergite IX with 16-18 trong median setae and 25-37 weaker setae on posterior subquadrangular extension; anal tergite bands covering about half of the tergite length. Laterosternite IX with 3-4 setae. Anal point bluntly triangular, 40-47 $\mu \mathrm{m}$ long, 13-15 $\mu \mathrm{m}$ wide at base. Transverse sternapodeme 75-109 $\mu \mathrm{m}$ long, straight. Phallapodeme 76-120 $\mu \mathrm{m}$ long. Gonocoxite 237-248 $\mu \mathrm{m}$ long. Superior volsella stout, evenly curved, 55-59 $\mu \mathrm{m}$ long, 19-25 $\mu \mathrm{m}$ wide medially, 6-7 $\mu \mathrm{m}$ wide subapically, with rounded base with microtrichia and 1-2 inner setae. Inferior volsella 80-102 $\mu \mathrm{m}$ long, with 7-8 $\mu \mathrm{m}$ long, bluntly triangular free tip, with 9-11 dorsal setae. Gonostylus 85-110 $\mu \mathrm{m}$ long. Hypopygium ratio (HR) 2.19-2.79. Hypopygium value (HV) 5.19-5.32.

FIGURES 3-4: Fissimentum mendesi n. sp., male; 3. Hypopygium, dorsal view; 4. Hypopygium with anal point and tergite IX removed dorsal aspect to the left and ventral aspect to the right.

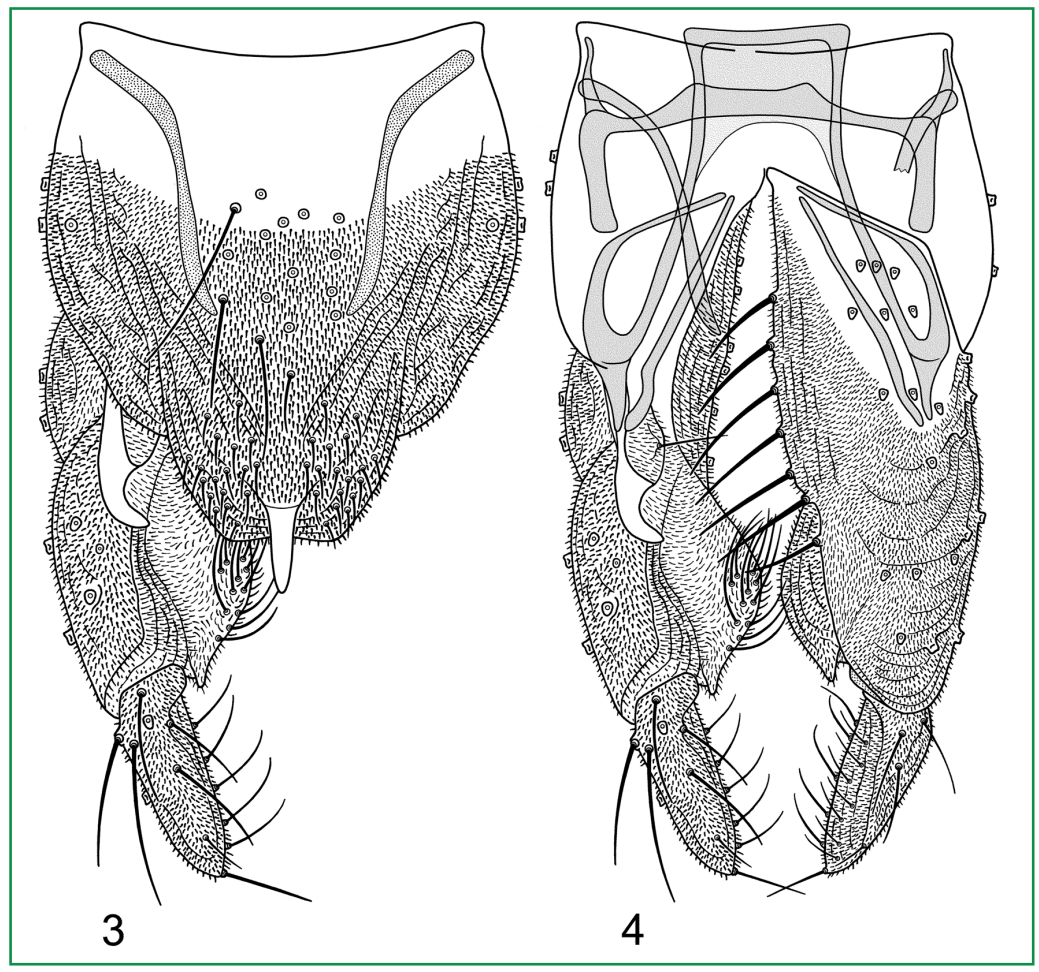

Female and immatures: Unknown. 


\section{Distribution and ecology}

The specimens were collected in light traps in large and shallow streams with substrate of stones and gravel at altitudes between 570 and $930 \mathrm{~m}$. Furnas do Bom Jesus State Park comprises an area of 2,069.06 ha of Cerrado and Atlantic Forest vegetation, including part of the drainage basin of the "Pedregulho" Brook, and it is a representative area of the regional ecosystem called "Furnas do Rio Grande" (BRANCO et al., 2001).

\section{Etymology}

Named after Dr. Humberto Fonseca Mendes, for his friendship and contribution to Neotropical chironomidology.

\section{Acknowledgements}

We are indebted to Hege Avsnes Dale, Institute for Biomedicine, University of Bergen, for taking the photographs of the wings.

\section{References}

BRANCO, I. H. D. C.; DOMINGUES, E. N.; SÉRIO, F. C.; DEL CALI, I. H.; MATTOS, I. F. A.; BERTONI, J. E. A.; ROSSI, M.; ESTON, M. R.; PFEIFER, R. M.; ANDRADE, W. J. Plano Conceitual de Manejo - Parque Estadual das Furnas do Bom Jesus, Município de Pedregulho, SP. Revista do Instituto Florestal, São Paulo, v. 3, p. 137-155, 1991.

CRANSTON, P. S.; NOLTE, U. Fissimentum, a new genus of drought-tolerant Chironomini (Diptera: Chironomidae) from the Americas and Australia. Entomological News, Philadelphia, v. 107, p. 1-15, 1996.

EPLER, J. Checklist of the Chironomidae of Florida. 2009. (Updated 26 March 2019). Available at: <http://johnepler.com/ FLchiro.html>.

PINHO, L. C.; FROEHLICH, C. G. Three new neotropical species of Fissimentum Cranston \& Nolte, 1996 (Diptera: Chironomidae: Chironominae). In: WANG, X.; LIU, W. (Ed.). Contemporary Chironomid Studies - Proceedings of the 17th International Symposium on Chironomidae (July 6-9, 2009, Nankai University, China). Nankai University Press, Nankai, 2011. p. 144-153.

ROBACK, S. S. The Catherwood Foundation Peruvian-Amazon Expedition. XII Diptera, with some observations on the salivary glands of the Tendipedidae. Monographs of the Academy of Natural Sciences of Philadelphia, Philadelphia, v. 14, p. 305-375, 1966.

SÆTHER, O. A. Some Nearctic Podonominae, Diamesinae, and Orthocladiinae (Diptera: Chironomidae). Bulletin of the Fisheries Research Board of Canada, Ottawa, v. 107, p. 1-154. 1969.

SÆTHER, O. A. Glossary of Chironomid morphology terminology (Diptera: Chironomidae). Entomologica Scandinavica, Lund, v. 14, Supplement, p. 1-51, 1980. 